\title{
KONSEP PEMBUKTIAN SEDERHANA DALAM PERKARA KEPAILITAN
}

\author{
Kajian Putusan Nomor 125 PK/PDT.SUS-PAILIT/2015
}

\section{SIMPLE PROOF CONCEPT IN THE PROCEEDING OF BANKCRUPTCY}

\author{
An Analysis of Court Decision Number 125 PK/PDT.SUS-PAILIT/2015
}

\author{
Nelson Kapoyos \\ Lembaga Studi Hukum Indonesia \\ Jl. Haji Nawi Raya No. 10B, Jakarta Selatan 12420 \\ E-mail: nkapoyos@yahoo.com
}

Naskah diterima: 12 Oktober 2017; revisi: 4 Desember 2017; disetujui 18 Desember 2017

http://dx.doi.org/10.29123/jy.v10i3.264

\begin{abstract}
ABSTRAK
Penelitian ini mempermasalahkan pembuktian sederhana dalam proses kepailitan terkait kewajiban pemberitahuan adanya peralihan piutang (cessie) kepada debitur. Putusan Nomor ０2/PDT.SUS.PAILIT/2014/PN.Niaga.Mks telah mengabulkan permohonan kreditur cessionaries yang dikuatkan oleh Putusan Nomor 19 K/PDT.SUSPAILIT/2015, namun pada upaya hukum peninjauan kembali majelis hakim justru mengabulkan permohonan peninjauan kembali dengan alasan pembuktian sederhana terhadap cessie belum diberitahukan kepada debitur secara resmi melalui juru sita pengadilan. Rumusan masalah penelitian ini ialah bagaimana konsep pembuktian sederhana dalam kepailitan terhadap kewajiban pemberitahuan pengalihan piutang (cessie) pada pertimbangan majelis hakim peninjauan kembali Nomor 125 PK/PDT.SUS-PAILIT/2015. Metode penelitian ini menggunakan penelitian hukum normatif. Kesimpulan penelitian ini adalah konsep pembuktian sederhana di dalam pembuktian kepailitan tidak ada kewajiban pemberitahuan secara resmi melalui juru sita pengadilan karena Pasal 613 BW tidak mengaturnya, pemberitahuan hanya diajukan secara tertulis dan bisa
\end{abstract}

kapanpun diberitahukan kepada debitur.

Kata kunci: kepailitan, pembuktian sederhana, cessie.

\section{ABSTRACT}

This analysis intends to question the simple proof in bankruptcy proceedings related to the transition of receivable notification obligation (cessie) to the debtors. The Commercial Court Decision Number 02/PDT.SUS. PAILIT/2014/PN.Niaga.Mks has granted the petitions of creditor's cessionary which was strengthened by the Supreme Court Decision Number 19 K/PDT.SUSPAILIT/2015, but on the judicial review attempt, the Supreme Court has granted the petition for the judicial review on the grounds that a simple proof of cessie has not been officially disclosed to the debtor through a court bailiff. The formulation of this research problem is how the concept of simple proof in bankruptcy proceeding to the obligation of notification of transfer of receivables (cessie) in the consideration of Court Decision Number 125 PK/PDT.SUS-PAILIT/2015. The research method of this analysis is normative legal research. This analysis resolves thatin the simple proof concept of the bankruptcy proceedings, there is no obligation of 
official notice through the court bailiff because it is not set on Article 613 of Indonesia Civil Code Law, so the notification is only submitted in writing and may at any time be notified to the debtor.

Keywords: bankruptcy, simple proof, cessie.

\section{PENDAHULUAN}

\section{A. Latar Belakang}

Masyarakat modern saat ini memang sangat membutuhkan adanya kepastian hukum dalam berbagai interaksi dengan sesama manusia, untuk mewujudkan hal itu peran utama diletakkan pada hukum yang tercermin dalam aturan. UndangUndang Kepailitan telah memberikan aturan main yang jelas, kepastian hukum berkaitan dengan prosedur mempailitkan debitur terdapat dalam ketentuan Pasal 8 ayat (4) bahwa hakim pengadilan niaga harus mempailitkan apabila terbukti secara sederhana unsur Pasal 2 ayat (1). Namun, pola yang demikian dalam operasionalnya telah menimbulkan persoalan ketidakadilan (Zulaeha, 2015: 178-179).

Kurangnya inkonsistensi Putusan Mahkamah Agung dan putusan pengadilan niaga dalam menentukan adanya pembuktian sederhana antara putusan yang satu dengan putusan yang lainnya dalam perkara kepailitan. Salah satu kasus pengajuan permohonan kepailitan yang dilakukan oleh kreditur pemegang hak cessie terakhir(cessionaries). Pada penelitian ini, majelis hakim pengadilan niaga mempertimbangkan pembuktian sederhana terhadap kewajiban bagi kreditur untuk melakukan pemberitahuan kepada debitur dalam kepailitan.

Putusan Nomor 125 PK/PDT.SUSPAILIT/2015. dalam pertimbangan hukumnya mempermasalahkan pembuktian sederhana terhadap pengalihan piutang (cessie). Kasus ini berawal dari utang yang dimiliki oleh debitur yakni PT HI yang telah menandatangani perjanjian fasilitas kredit investasi dengan Bank PI sebagaimana yang termaktub dalam Akta Perjanjian Kredit Jangka Menengah dan Panjang Nomor 85 tanggal 31 Oktober 1988. Piutang dari Bank PI kemudian diahlikan ke BPPN dan terakhir pengalihan piutang dipegang oleh perusahaan GPF, proses pengalihan piutang dalam bentuk cessie ini telah dibuat berdasarkan Akta Nomor 85 tanggal 31 Oktober 1988 tersebut, akta jual beli piutang (cessie) dari Bank BI kepada BPPN dan terakhir akta jual beli dan cessie kepada GPF.

GPF sebagai kreditur terakhir dari proses pengalihan hak cessie, mempunyai hak tagih terhadap utang yang dimiliki oleh debitur PT HI. GPF sudah beberapa kali mengajukan somasi kepada debitur yang sampai terakhir mengajukan somasi mengirimkan notice of default dengan perhitungan kerugian sebesar US\$79,971,949, dan diketahui oleh pihak GPF, ternyata tidak hanya utang terhadap debitur PT HI namun juga terhadap ahli waris AS dan GS yang merupakan pemegang saham PT HI yang telah bersedia menanggung utang (borgtocht) untuk melunasi utang-utang debitur.

Kreditur mengajukan somasi terhadap debitur namun tidak ada tanggapan dari debitur, kemudian GPF mengajukan permohonan pernyataan pailit melalui pengadilan niaga pada Pengadilan Negeri Makassar yang teregister dengan Nomor 02/PDT.SUS.PAILIT/2014/ PN Niaga.Mks, GPF mengajukan permohonan pailit terhadap debitur PT HI dan ahli waris AS dan GS yang telah melepaskan hak istimewanya 
dalam akta penanggungan untuk menanggung seluruh utang debitur, karena menurutnya telah memenuhi unsur-unsur permohonan pailit yang diatur di dalam Pasal 2 ayat (1) Undang-Undang Nomor 37 Tahun 2004 tentang Kepailitan dan Penundaan Kewajiban Pembayaran Utang, yakni adanya utang yang telah jatuh waktu dan dapat ditagih serta memenuhi unsur adanya kreditur lain yaitu perusahaan VIH Ltd.

Berdasarkan fakta persidangan, debitur sebagai termohon pailit memohon kepada majelis hakim pengadilan niaga untuk menolak permohonan pailit dari kreditur GPF karena termohon pailit tidak pernah merasa diberitahukan terhadap akta perjanjian pengalihan piutang (cessie) Nomor 19 tanggal 17 Juli 2008 dan akta perjanjian pengalihan piutang (cessie), sehingga harus dibuktikan secara rumit di pengadilan perdata untuk membuktikan pengalihan piutang telah sesuai dengan apa yang tercantum di dalam Pasal 613 Burgerlijk Wetboek (BW).

Berdasarkan permohonan pailit yang diajukan oleh GPF, majelis hakim pengadilan niaga telah menjatuhkan Putusan Nomor 02/ PDT.SUS.PAILIT/2014/PN.Niaga.Mks, adapun ringkasan amarnya putusannya yakni menerima dan mengabulkan seluruh permohonan pailit, menyatakan termohon pailit I, termohon pailit II, dan termohon pailit III, pailit dengan segala akibat hukumnya. Terhadap hasil putusan tersebut pihak ahli waris AS dan GS mengajukan upaya hukum kasasi, dalam permohonannya juga mempermasalahkan mengenai keabsahan penggunaan cessie di dalam proses permohonan kepailitan, namun dalam amar Putusan Nomor 19 K/PDT.SUS-PAILIT/2015, menolak seluruh permohonan kasasi dari pemohon kasasi dan menguatkan Putusan Nomor 02/PDT.SUS. PAILIT/2014/PN.Niaga.Mks.
Pihak ahli waris mengajukan upaya hukum terakhir yakni permohonan peninjauan kembali di kepaniteraan Pengadilan Negeri/Niaga Makassar pada tanggal 21 Oktober 2015, dengan amar putusan dalam Putusan Nomor 125 PK/ PDT.SUS-PAILIT/2015 berpendapat lain yang justru mengabulkan permohonan pemeriksaan peninjauan kembali dari para pemohon peninjauan kembali. Di dalam pertimbangan majelis hakim peninjauan kembali memberikan pendapatnya yang menyatakan bahwa:

"Tidak diperoleh bukti yang cukup bahkan tidak ada bukti sama sekali kalau cessie tersebut telah diberitahukan kepada si berutang sebagaimana diatur di dalam Pasal 613 KUHPerdata, mempedomani Putusan MA RI Nomor $18 \mathrm{~K} / \mathrm{N} / 2000$ antara BPPN melawan PT SA dalam pertimbangan yang menyatakan akta cessie tidak sesuai dengan Pasal 613 KUHPerdata, yang antara lain tidak diberitahukan kepada pihak debitur atau yang berhutang, sehingga demikian keabsahan akta cessie masih harus dipermasalahkan, maka dengan demikian permohonan pailit a quo tidak memenuhi syarat pembuktian yang sederhana."

Pertimbangan majelis hakim peninjauan kembali mempedomani Putusan MA RI Nomor $18 \mathrm{~K} / \mathrm{N} / 2000$ yang menyatakan pembuktian sederhana wajib diberitahukan kepada debitur secara resmi dengan eksploit juru sita pengadilan (betekend), pandangan tersebut juga mengoreksi pertimbangan hukum pada pengadilan niaga dan kasasi yang menafsirkan berbeda atas pembuktian terhadap adanya peralihan piutang (cessie) melalui pemberitahuan terhadap debitur.

\section{B. Rumusan Masalah}

Berdasarkan latar belakang di atas maka penulis membuat rumusan masalah yakni bagaimanakah konsep pembuktian sederhana terhadap kewajiban pemberitahuan pengalihan 
piutang (cessie) dalam kepailitan pada Putusan Nomor 125 PK/PDT.SUS-PAILIT/2015?

\section{Tujuan dan Kegunaan}

Tujuan dari penelitian ini adalah untuk menemukan konsep pembuktian sederhana terhadap kewajiban pemberitahuan pengalihan piutang (cessie) dalam perkara kepailitan pada Putusan Nomor 125 PK/PDT.SUS-PAILIT/2015. Sedangkan kegunaan penelitian secara teoritis, memberikan pemahaman, wawasan pengetahuan bagi para akademisi terkait dengan ketentuan yang mengatur mengenai teori penggunaan cessie dihubungan dengan teori mengenai hukum kepailitan.

Kegunaan secara praktis bagi majelis hakim yang menangani kepailitan serta pembuat undang-undang agar dapat memberikan kepastian hukum dan keadilan mengenai perlindungan hukum bagi kreditur cessie dalam mengajukan proses permohonan pailit.

\section{Tinjauan Pustaka \\ 1. Hukum Pembuktian}

Prinsip pembuktian di dalam keperdataan ditentukan dalam Pasal 163 Herzien Inlandsch Reglemen (HIR), yang menyatakan bahwa:

"Barang siapa menyatakan mempunyai hak atas suatu barang, atau menunjuk suatu peristiwa untuk meneguhkan haknya, ataupun menyangkal hak orang lain, maka orang itu harus membuktikannya."

Untuk meneguhkan hak seseorang atau untuk membantah hak orang lain, undang-undnag menentukan alat-alat bukti yang dapat diajukan dalam proses penyelesaian perkara perdata adalah sebagaimana yang disebutkan dalam Pasal 164 HIR yang terdiri dari bukti tertulis, bukti saksi, persangkaan, pengakuan, dan sumpah (Juanda, 2016: 28).

Prinsip pembuktian tersebut maka hakim wajib memberikan beban pembuktian kepada penggugat untuk membuktikan dalil atau peristiwa yang dapat mendukung dalil tersebut, yang diajukan oleh penggugat, sedangkan bagi tergugat, hakim wajib memberikan suatu beban pembuktian untuk membuktikan bantahannya atas dalil yang diajukan oleh para penggugat. Hakim hendaknya tidak begitu saja secara harfiah melaksanakan asas pembuktian, tetapi hakim harus bijaksana dan pantas, yaitu hendaknya hakim meletakkan keharusan membuktikan kepada pihak yang paling gampang untuk membuktikan, dan tidak membebani kepada pihak yang paling sulit untuk membuktikan, terkhusus pada perkara yang didasarkan pada suatu hubungan hukum yang timbul tanpa adanya alat bukti tulisan atau surat (dilakukan secara lisan) oleh para pihak (Wahyudi, 2012: 122).

Sistem hukum pembuktian yang dianut di Indonesia adalah sistem tertutup dan terbatas di mana para pihak tidak bebas mengajukan jenis atau bentuk alat bukti dalam proses penyelesaian perkara. Undang-undang telah menentukan secara tegas apa saja yang sah dan bernilai sebagai alat bukti. Pembatasan kebebasan juga berlaku bagi hakim di mana hakim tidak bebas dan leluasa menerima apa saja yang diajukan para pihak sebagai alat bukti. Apabila pihak yang berperkara mengajukan alat bukti di luar ketentuan yang ada di dalam undang-undang yang mengatur, hakim harus menolak dan mengesampingkannya dalam penyelesaian perkara (Harahap, 2012: 554-555).

Pada pembuktian perdata, hakim harus mengakui kebenaran peristiwa yang bersangkutan yang hanya dapat diperoleh melalui proses 
pembuktian untuk dapat menjatuhkan putusan yang dirasakan adil, maka hakim harus mengenal peristiwa yang telah dibuktikan kebenarannya. Membuktikan dalam hukum acara mempunyai arti yuridis, yaitu pembuktian hanya berlaku bagi pihak-pihak yang berperkara. Pembuktian dalam hukum bersifat historis artinya pembuktian yang mencoba menetapkan apa yang telah terjadi secara konkret (Butarbutar, 2010: 356).

\section{Penyerahan/Peralihan Piutang (Cessie)}

Menurut Suharnoko \& Hartati (2012: 1) cessie adalah suatu pengalihan piutang atas nama yang diatur di dalam Pasal 613 KUHPerdata yang terjadi melalui jual beli antara kreditur yang lama dengan kreditur yang baru. Jadi, utang yang lama tidak dihapus tetapi beralih kepada pihak ketiga sebagai kreditur baru. Agar cessie dapat dilaksanakan maka cessie harus diberitahukan kepada cessus (pihak debitur dari piutang atas nama).

Pandangan mengenai cessie juga dikemukakan oleh Asser (1991: 579-580) bahwa cessie adalah pengambilalihan piutang. Pengambilalihan piutang tersebut tidaklah menghilangkan identitas dari utang itu dan pada umumnya tidak berpengaruh terhadap hubungan antara si berutang dengan si berpiutang.

Praktiknya penggunaan cessie biasanya terjadi karena kreditur membutuhkan uang. Sehingga ia menjual piutangnnya kepada pihak ketiga yang akan menerima pembayaran dari debitur pada saat piutang tersebut jatuh tempo. Pihak yang mengalihkan atau menyerahkan disebut cedent. Sedangkan pihak yang menerima pengalihan atau penyerahan disebut cessionaries. Lalu debitur dari tagihan yang dialihkan atau diserahkan disebut cessus (Budiono, 2010: 85).
Menurut Satrio yang dikutip oleh Baskara (2014: 3): Dengan cessie, maka seorang kreditur baru berhak untuk menagih utang debitur dan apabila debitur wanprestasi. Pemindahan itu harus dilakukan dengan suatu akta otentik atau di bawah tangan; jadi tak boleh dengan lisan atau dengan penyerahan piutangnya saja. Agar pemindahan berlaku terhadap si berutang, akta cessie tersebut harus diberitahukan padanya secara resmi (betekend). Hak piutang dianggap telah berpindah pada waktu akta cessie itu dibuat, jadi tidak pada waktu akta itu diberitahukan pada si berutang.

Mengenai konsep pemberitahuan peralihan piutang cessie terhadap debitur memang wajib diberitahukan, namun menurut Vollmar, mengatakan sebagai berikut:

"Meskipun cessie telah sah dengan dibuatnya akta cessie yang mengakibatkan beralihnya hak tagih, tetapi untuk mengikat cessus atau debitur, berdasarkan Pasal 613 ayat (2) KUHPerdata pengalihan tersebut harus diberitahukan kepada debitur atau telah diakui atau disetujui oleh debitur (betekening). Kelalaian dalam pemberitahuan kepada cessus berakibat bahwa pembayaran tagihan yang dilakukan oleh cessus kepada cedent atau debitur lama tetap sah, asal cessus dengan jujur beranggapan bahwa cedent masih sebagai krediturnya" (Cahyono, 2004: 17-18).

Berbeda halnya dengan konsep kewajiban pemberitahuan terhadap debitur atau cessus dalam cessie menurut Badrulzaman (1984: 105-106) berpendapat Pasal 613 ayat (2) KUHPerdata mewajibkan adanya pemberitahuan pada debitur/cessus, namun hal itu tidak perlu adanya pemberitahuan pada debitur/cessus. Sedangkan menurut Setiawan \& Satrio (2010: 23) mengatakan sebagai berikut:

"Dalam praktik di masa sekarang, dari laporan para lawyer yang sampai pada 
penulis, syarat seperti itu membawa banyak kesulitan dalam praktik, karena sekarangdi samping masalah biaya-para juru sita sudah sangat sibuk dengan tugas-tugasnya sehingga tidak mudah untuk minta agar juru sita menyempatkan waktu untuk memberitahukan telah terjadinya cessie kepada cessus, sehingga tidak perlu pakai eksploit juru sita."

\section{Hukum Kepailitan}

Kepailitan merupakan sitaan umum yang mencakup seluruh kekayaan debitur untuk kepentingan semua krediturnya. Tujuan kepailitan adalah pembagian kekayaan debitur oleh kurator kepada semua kreditur dengan memperhatikan hak-hak mereka masing-masing (Suci \& Poesoko, 2016: 64).

Kartono memberikan pendapatnya mengenai kepailitan yakni mengatakan bahwa kepailitan adalah suatu sitaan dan eksekusi atas seluruh harta kekayaan debitur untuk kepentingan seluruh kreditur bersama-sama, yang pada waktu si debitur dinyatakan pailit mempunyai piutang dan untuk jumlah piutang yang masing-masing kreditur memiliki pada saat itu (Rochmawanto, 2015: 28).

Terminologi kepailitan (bankrupt) berkorelasi dengan kata insolvency, arti kata ini dalam Black's Law Dictionary adalah “the condition of being unable to pay debts as they fall due or in the ussual course of business." Apabila diterjemahkan secara bebas berarti keadaan di mana seseorang atau badan hukum tidak mampu membayar utang mereka pada saat jatuh tempo (Pratama, 2014: 160).

Menurut Purwadi (2011: 131) kepailitan adalah keadaan hukum yang ditetapkan oleh pengadilan niaga di mana seorang debitur tidak mampu ataupun tidak mau membayar paling sedikit satu utang yang telah jatuh tempo dan dapat ditagih dan sebagai konsekuensi hukum dari kepailitan tersebut semua harta kekayaan debitur maupun yang ada pada saat pernyataan pailit.

Pembentukan Undang-Undang Nomor 37 Tahun 2004 tentang Kepailitan diatur mengenai asas-asas kepailitan yang tercantum di dalam Penjelasan Undang-Undang Kepailitan yakni asas integrasi, asas keseimbangan, asas keadilan, dan asas kelangsungan usaha. Terkait dengan asas keseimbangan menyatakan bahwa undang-undang ini hanya mengatur beberapa ketentuan dari asas keseimbangan yang di satu pihak terdapat ketentuan yang dapat mencegah terjadinya penyalahgunaan pranata lembaga kepailitan oleh debitur yang tidak jujur, di lain pihak terdapat ketentuan yang dapat mencegah terjadinya penyalahgunaan pranata dan lembaga kepailitan oleh kreditur yang tidak beriktikad baik (Usman, 2016: 154).

Mengenai syarat-syarat kepailitan yang dapat diajukan ke pengadilan setidaknya harus memenuhi beberapa unsur sebagaimana dijelaskan di dalam Pasal 2 ayat (1) UndangUndang Nomor 37 Tahun 2004 yang memberikan ketentuan sebagai berikut:

Debitur yang mempunyai dua atau lebih kreditur dan tidak membayar lunas sedikitnya satu utang yang telah jatuh tempo dan dapat ditagih, dinyatakan pailit dengan putusan pengadilan, baik atas permohonannya sendiri maupun atas satu atau lebih kreditur.

Shubhan (2014: 67) berpendapat Pasal 1 dan Pasal 2 ayat (1) Undang-Undang Nomor 37 Tahun 2004, yang menyatakan beberapa unsur dalam mengajukan permohonan pailit yaitu: 
"Pengertian yang termuat dalam Pasal 1 Undang-Undang Kepailitan dan dihubungkan dengan persyaratan pengajuan pernyataan pailit sebagaimana diuraikan dalam Pasal 2 Undang-Undang Kepailitan, ternyata kepailitan mengandung unsurunsur adanya debitur yang mempunyai dua orang atau lebih kreditur dan tidak membayar satu utang yang telah jatuh tempo dan utang tersebut sifatnya dapat ditagih maka dapat dipailitkan melalui putusan pengadilan dengan diletakkannya sita umum atas harta debitur pailit yang pengurusan dan pemberesannya dilakukan oleh kurator dan pengurus di bawah pengawasan hakim pengawas."

Sebagaimana penjelasan mengenai Pasal 2 ayat (1) Undang-Undang Nomor 37 Tahun 2004 juga mengisyaratkan bahwa hakim memutus berdasarkan pembuktian sederhana. Proses pembuktian sederhana dalam proses permohonan pailit harus terpenuhi sebagaimana dijelaskan di dalam Pasal 8 ayat (4) yang menyatakan sebagai berikut:

Permohonan pernyataan pailit harus dikabulkan apabila terdapat fakta atau keadaan yang terbukti secara sederhana bahwa persyaratan untuk dinyatakan pailit sebagaimana dimaksud dalam Pasal 2 ayat (1) telah dipenuhi.

Pada proses kepailitan undang-undang hanya menentukan dalam Pasal 8 ayat (4) bahwa permohonan dapat dibuktikan secara sederhana sebagaimana yang dimaksud dalam Pasal 2 ayat (1) telah terpenuhi. Syarat kepailitan yang dimaksud dalam Pasal 2 ayat (1) yang menyatakan adanya dua atau lebih kreditur dan tidak membayar utang yang telah jatuh waktu dan dapat ditagih. Namun Undang-Undang Nomor 37 Tahun 2004 tidak memberikan penjelasan secara rinci mengenai bagaimana pembuktikan sederhana dilakukan sehingga pelaksanaan dan penafsiran dilakukan sepenuhnya oleh majelis hakim yang memeriksa dan memutus perkara kepailitan yang bersangkutan (Putriyanti \& Wijayanta, 2010: 483).

Pembuktian sederhana dalam praktik di pengadilan niaga, menjadi tidak sesederhana sebagaimana yang dimaksud dalam Pasal 8 ayat (4) Undang-Undang Kepailitan. Puang (2011: iii) berpendapat bahwa sering terjadi adanya penafsiran berbeda-beda atau inkonsistensi penafsiran di kalangan majelis hakim tentang ketidakjelasan pengertian pembuktian sederhana.

Dalam praktiknya pembuktian sederhana dalam proses permohonan kepailitan bagi kreditur pemegang hak cessie juga demikian halnya, dengan menolak permohonan pemegang hak cessie dengan alasan pembuktiannya tidaklah sederhana.

Pendapat yang berkembang berkaitan dengan pembuktian sederhana pada masa faillissementsverordening antara lain pembuktian tentang debitur dalam keadaaan berhenti membayar harus dilakukan secara sederhana (summier). Artinya, pengadilan di dalam memeriksa permohonan pernyataan pailit tidak perlu terikat dengan sistem pembuktian dan alatalat bukti yang ditentukan dalam hukum acara perdata.

Ketentuan pembuktian sederhana ini mewajibkan pembuktian persyaratan kepailitan dalam hal adanya dua atau lebih kreditur dan minimal. Tidak adanya definisi dan batasan yang jelas dalam penggunaan pembuktian sederhana sehingga membuka perbedaan yang semakin lebar di antara para hakim menafsirkan pengertian pembuktian sederhana dalam menyelesaikan perkara kepailitan (Sunarmi, 2016: 30-31). 


\section{METODE}

Metode penelitian yang digunakan dalam penelitian ini adalah metode penelitian hukum normatif yaitu penelitian hukum teoritis/dogmatis karena tidak mengkaji pelaksanaan ataupun implementasi hukum, namun hanya menekankan melalui data sekunder (Saifullah, 2015: 122). Dalam penelitian normatif ini yakni melakukan inventarisasi hukum positif pengaturan di dalam Burgerlijk Wetboek dan Undang-Undang Nomor 37 Tahun 2004 mengenai ketentuan cessie dalam proses pengajuan permohonan kepailitan.

Pendekatan penelitian ini mengkaji dan menganalisis peraturan perundang-undangan dan kasus yang berkaitan dengan hal-hal yang menjadi permasalahan. Dalam hal ini mengkaji studi kasus Putusan Nomor 125 PK/PDT.SUSPAILIT/2015 dan menyesuaikan terhadap Burgerlijk Wetboek dan Undang-Undang Nomor 37 Tahun 2004, di samping itu juga mengkaji teori-teori dan doktrin dari para ahli hukum yang berhubungan dengan kepailitan dan cessie. Sumber data dalam penelitian ini menggunakan data sekunder yang terdiri dari bahan hukum primer, bahan hukum sekunder, dan bahan hukum tersier (Amiruddin \& Asikin, 2010: 118-119).

Mengenai fokus penelitian ini maka data analisisnya menggunakan deskriptif kualitatif dengan menganalisis dan menemukan konsep yang ideal pembuktian Sederhana dalam kepailitan terhadap kewajiban pemberitahuan pengalihan piutang (cessie) kepada debitur, sehingga dengan menggunakan analisis deskreptif analisis pemegang hak cessie dalam hal ini cessionaries mendapatkan kepastian hukum untuk mengajukan permohonan kepailitan karena dalam praktik putusan pengadilan tidak memberikan konsistensi serta kepastian hukum bagi pemegang hak cessie dalam mengajukan upaya hukum kepailitan terhadap pembayaran utang kepada debitur yang mengisyaratkan pembuktian sederhana akta pengalihan piutang cessie yang wajib diberitahukan oleh debitur.

\section{HASIL DAN PEMBAHASAN}

Pengaturan mengenai pengalihan piutang dari kreditur lama ke kreditur yang baru dalam hal ini cessie, jika dihubungkan dengan UndangUndang Nomor 37 Tahun 2004 memang tidak diatur secara tegas. Namun dalam asas UndangUndang Nomor 37 Tahun 2004 telah disebutkan mengenai asas integrasi yang menyatakan bahwa sistem hukum formal dan hukum materielnya merupakan satu kesatuan yang utuh dari sistem hukum perdata dan hukum acara perdata nasional. Oleh karena itu, jika di dalam Undang-Undang Nomor 37 Tahun 2004 tidak mengatur secara tegas pengaturan permohonan hak pemegang cessie yang diistilahkan kreditur baru, maka pengaturan di dalam Pasal 613 BW tentang cessie juga dapat dikaitkan di dalam pertimbangan-pertimbangan hukum bagi majelis hakim pengadilan niaga dalam memutus perkara kepailitan.

Ketentuan mengenai kewajiban bagi kreditur pemegang hak cessie dalam Pasal 613 BW, adapun bunyinya yakni sebagai berikut:

1) Penyerahan akan piutang-piutang atas nama dan kebendaan tak bertubuh lainnya, dilakukan dengan jalan membuat sebuah akta otentik atau di bawah tangan, dengan mana hak-hak atas kebendaan tersebut dilimpahkan kepada orang lain.

2) Penyerahan yang demikian bagi si berutang tiada akibat, melainkan setelah penyerahan itu diberitahukan kepadanya atau secara tertulis disetujui dan diakui.

3) Penyerahan tiap-tiap piutang karena surat bawa dilakukan dengan menyerahkan 
surat itu; penyerahan tiap-tiap piutang karena surat-surat tunjuk dilakukan dengan penyerahan surat disertai dengan endosmen.

Berdasarkan Pasal 613 BW di atas, menyatakan pengertian cessie yakni adanya penyerahan piutang dari kreditur lama ke kreditur baru yang dibuat berdasarkan akta tertulis (otentik atau bawah tangan), sehingga akibat hukumnya utang bagi debitur (cessus) tidak akan dihapus namun tetap ada, dalam hal ini yang menagih utangnya ialah kreditur terakhir (cessionaries) yang telah menerima penyerahan piutang tersebut.

Mengacu pada Pasal 613 BW ayat (2) dijelaskan terhadap pengalihan piutang adanya kewajiban untuk diberitahukan atau secara tertulis disetujui dan diakui. Yurisprudensi Mahkamah Agung Nomor $48 \mathrm{~K} / \mathrm{PDT} / 2000$ tanggal 18 Oktober 2002, majelis hakim menafsirkan terhadap ketentuan Pasal 613 BW dalam pertimbangannya menyatakan bahwa dalam jual beli piutang tidak ada aturan yang mengatur atau mengharuskan para pihak yang terlibat jual beli piutang untuk memberitahukan kepada debitur bahwa utangnya telah dialihkan/dijual.

Mengenai kedudukan pemegang hak cessie atau dalam hal ini kreditur baru (cessionaris) yang telah beralih dari kreditur lama, mempunyai kedudukan menggantikan kreditur lama dalam hal menagih segala utang debitur (cessus) apabila debitur tersebut cedera janji tidak menghapus segala kewajibannya dari utang tersebut, dan pemegang hak cessie mempunyai kuasa untuk menagih dengan pembuktian adanya akta cessie yang telah disepakati oleh kreditur lama.

Cessionaries mempunyai hak tuntutan apapun untuk menagih utang debitur yang telah jatuh tempo dan dapat ditagih, kedudukan hak tersebut sama halnya dengan kreditur lama, salah satu upaya yang juga dapat dilakukan dengan mengajukan upaya proses permohonan kepailitan. Namun di dalam praktik putusan pengadilan niaga dan Putusan Mahkamah Agung terdapat pertimbangan majelis hakim yang berbeda dalam menerapkan status cessie, salah satu yang menjadi permasalahan yang timbul adanya kewajiban bahwa cessie wajib diberitahukan, hakim mempunyai penafsiranpenafsiran tersendiri dalam memutus perkara kepailitan, sehingga justru tidak memberikan perlindungan hukum terhadap hak kreditur baru (cessionaries) untuk mendapatkan pelunasan utang-utangnya.

Perlindungan hukum bisa berarti perlindungan yang diberikan terhadap hukum agar tidak ditafsirkan berbeda dan tidak dicederai oleh aparat penegak hukum dan juga bisa berarti perlindungan yang diberikan oleh hukum terhadap sesuatu apapun yang melanggar hakhak individu yang dirugikan. Mengacu pada pendapat tersebut, setidaknya ada perubahan yang mengatur mengenai cessie sehingga tidak timbul penafsiran-penafsiran majelis hakim dalam menangani perkara kepailitan. Dalam beberapa putusan perkara kepailitan mengabulkan permohonan pemohon kreditur pemegang hak cessie (cessionaries), dan mempailitkan debitur, namun di dalam putusan yang lainnya justru menolak seluruh permohonan kreditur cessionaries, yang menyatakan dalam pembuktiannya pemohon tidak dapat membuktikan secara sederhana pengajuan proses kepailitan.

Pembuktian sederhana ini dalam praktik di pengadilan niaga, menjadi tidak sesederhana sebagaimana yang dimaksud dalam Pasal 8 
ayat (4) Undang-Undang Kepailitan. Puang berpendapat bahwa sering terjadi adanya penafsiran berbeda-beda atau inkonsistensi penafsiran di kalangan majelis hakim tentang ketidakjelasan pengertian pembuktian sederhana. Dalam praktiknya pembuktian sederhana dalam proses permohonan kepailitan bagi kreditur pemegang hak cessie juga demikian halnya, dengan menolak permohonan pemegang hak cessie dengan alasan pembuktiannya tidaklah sederhana.

Salah satu kasus perkara Putusan Nomor 125 PK/PDT.SUS-PAILIT/2015 yang diajukan oleh pemohon ahli waris AS dan GS. Salah satu perkara ini mempermasalahkan adanya keabsahan dalam Pasal 613 BW yang menurutnya proses peralihan piutang dari Bank PI sampai ke GPF sebagai pemegang hak cessie sama sekali tidak pernah diberitahukan ataupun diakui oleh pemohon peninjauan kembali sehingga status kreditur masih perlu dibuktikan status krediturnya melalui mekanisme kepailitan.

PutusanNomor02/PDT.SUS.PAILIT/2014/ PN.Niaga.Mks, dalam permohonannya pihak GPF menjelaskan perkara ini berawal dari PT HI dalam usahanya guna membiayai pembangunan pabrik kayu lapis terpadu yang berlokasi di Sorong Irian Jaya. PT HI selaku debitur telah menandatangani perjanjian kredit investasi dengan Bank PI sebagaimana termaktub dalam Akta Perjanjian Kredit Jangka Menengah dan Panjang Nomor 85 tanggal 31 Oktober 1988.

GPF adalah pembeli/pemegang terakhir piutang/tagihan Bank PI kepada PT HI berdasarkan Akta Nomor 85 tanggal 31 Oktober 1988 vide akta jual beli piutang dan cessie dari Bank PI kepada BPPN; dan terakhir akta jual beli dan cessie kepada pemohon pailit yaitu GPF.
Maka GPF adalah kreditur dan PT HI adalah debitur dari pemohon pailit, GPF. GPF telah berkali-kali meminta kepada PT HI untuk segera melunasi seluruh kewajibannya yang telah jatuh tempo yang sampai dengan surat tanggal 24 Juli 2014 (notice of default) seluruhnya berjumlah US\$79,971,949.05, namun demikian tidak memenuhi kewajibannya dalam melunasi piutang kredit yang seharusnya merupakan kewajiban debitur.

Dalam perjanjian kredit berdasarkan Akta Nomor 85 tanggal 31 Oktober 1988 vide akta jual beli piutang dan cessie dari Bank PI kepada BPPN, GPF juga mempunyai piutang dengan pemegang jaminan perorangan dalam hal ini alm. ahli waris AS dan kemudian ahli waris kedua GS. Selanjutnya untuk dikabulkannya permohonan pailit kreditur pemohon menarik adanya kreditur lain yakni VIH Ltd. Bahwa kreditur lain juga mempunyai utang dengan debitur PT HI yang sebagai pembeli/pemegang terakhir piutang/ tagihan NIOSA kepada termohon pailit I berdasarkan Akta Nomor 61 tanggal 29 Oktober 1993 (bukti P-9), dan terakhir dijual ke VIH Ltd sebagai pembeli.

Kewajiban utang yang harus dipenuhi oleh termohon pailit I PT HI kepada VIH Ltd sampai dengan tanggal 28 Juli 2014 seluruhnya berjumlah JPY4,045,666,360.03. Bahwa sampai dengan diajukannya permohonan pailit oleh kreditor GPF belum dilunasi utang tersebut. Mengenai kewajiban yang harus dibayar kepada VIH Ltd, ahli waris AS dan GS sebagai termohon pailit II dan termohon pailit III yang pewarisnya telah melepaskan hak istimewanya untuk menanggung segala utang PT HI juga bertanggung jawab terhadap segala utang-utangnya tersebut, sama dengan utang yang harus dibayar kepada GPF. Pemohon pailit memohon kepada majelis hakim 
pengadilan niaga untuk mempailitkan debitur PT HI dan ahli waris AS dan GS.

Pertimbangan majelis hakim pada Putusan Nomor $\quad$ 02/PDT.SUS.PAILIT/2014/PN.Niaga. Mks, telah memberikan pertimbangan hukum dengan menafsirkan Pasal 613 BW serta Undang-Undang Nomor 37 Tahun 2004 terkait pembuktian sederhana, adapun pertimbangannya yakni sebagai berikut:

"Permohonan kepailitan pemegang hak cessie telah dibuktikan secara sederhana, mengenai harus dibuktikan pemberitahuan melalui cessie tidak menjadikan cessie tersebut tidak sah atau batal, cessie tetap sah dan kreditur GPF telah menjadi pemilik hak tagih, lagipula pemberitahuan tersebut telah disampaikan dengan adannya panggilan sidang oleh juru sita pengadilan niaga dalam permohonan yang diajukan oleh pemohon pailit GPF."

Pertimbangan majelis hakim pengadilan niaga jika dihubungkan dengan yurisprudensi Putusan Nomor $48 \mathrm{~K} / \mathrm{PDT} / 2000$ tanggal 18 Oktober 2002 sebagaimana penulis jelaskan sebelumnya mempunyai kesamaan mengenai kewajiban adanya pemberitahuan terhadap cessie kepada debitur. Pertimbangan majelis hakim selanjutnya telah menafsirkan mengenai diberitahukannya debitur, pemberitahuan cessie sebenarnya sudah diberitahukan pada saat pemanggilan sidang oleh juru sita pengadilan niaga, untuk hadir di dalam persidangan atas permohonan pailit GPF.

Mengenaipemberitahuanadanyapengalihan piutang cessie kepada debitur sebagaimana Pasal 613 BW ayat (2), bisa ditentukan kapan saja harus diberitahukan bahkan pada saat pengajuan proses permohonan ke pengadilan negeri yang diajukan oleh kreditur cessionaries juga merupakan suatu bentuk pemberitahuan, adanya pengalihan piutang tidak berarti menghapus utang, debitur tetap bertanggung jawab terhadap utang dan pemberitahuan pun tidak mesti pada saat penandatanganan akta cessie dari kreditur lama ke kreditur baru, karena memang di dalam Pasal 613 BW ketentuan mengenai cessie yang hanya satu pasal tidak mencantumkan secara jelas kapan harus diberitahukan.

Amar Putusan Nomor 02/PDT.SUS. PAILIT/2014/PN.Niaga.Mks adalah menerima dan mengabulkan seluruh permohonan pemohon pailit dari kreditur GPF (cessionaries), dan mempailitkan debitur PT HI, serta ahli waris AS dan GS. Kemudian ahli waris AS dan GS mengajukan upaya hukum melalui permohonan kasasi dengan Putusan Nomor 19 K/PDT. SUS-PAILIT/2015. Berdasarkan alasan-alasan pemohon kasasi tetap berdalih bahwa pemohon pailit tidak dapat membuktikan secara sederhana permohonan pailitnya, terhadap cessie yang semestinya diberitahukan kepada pemohon kasasi sebagai debitur (cessus). Namun majelis hakim kasasi berpendapat lain, adapun pertimbangannya sebagai berikut:

"Pengalihan piutang cessie sebagaimana syarat Pasal 613 BW. telah diberitahukan dibuktikan secara sederhana dengan adanya bukti notice of default dan pengakuan dari pemohon kasasi/termohon pailit I, di mana diketahui adanya utang yang telah jatuh tempo dan belum dibayar kepada termohon kasasi/pemohon pailit hingga saat permohonan pailit diajukan, di samping adanya utang pada kreditur lain yang belum pula dibayar, sehingga telah memenuhi persyaratan pengajuan pailit."

Pertimbangan majelis hakim kasasi berpendapat sama dengan majelis pengadilan niaga yang menyatakan pemohon pailit sudah membuktikan secara sederhana dengan telah diberitahukannya bukti notice of default dan 
pengakuan dari termohon pailit, sehingga memenuhi pembuktian sederhana dalam permohonan pailit. Pemberitahuan adanya peralihan piutang (cessie) diketahui oleh debitur pada saat diajukannya somasi oleh kreditur GPF dengan bukti lampiran notice of default, maka sejak saat itu debitur sudah mengetahui bahwa adanya pengalihan piutang.

Kuasa hukum dari ahli waris AS dan GS mengajukan jawaban atas permohonan pailit dari kreditur cessionaries GPF. Adapun yang dipermasalahkan oleh termohon pailit II dan termohon pailit III yakni menyatakan bahwa pembuktian yang diajukan oleh kreditur bukanlah pembuktian sederhana, karena menurut termohon pailit II dan termohon pailit III tidak pernah merasa diberitahukan adanya peralihan piutang (cessie) kepadanya.

Majelis hakim kasasi memberikan amar putusan dengan menolak seluruh permohonan pemohon kasasi, sehingga atas Putusan Nomor 19 K/PDT.SUS-PAILIT/2015, serta menguatkan Putusan Nomor 02/PDT.SUS.PAILIT/2014/ PN.Niaga.Mks tersebut. Kemudian ahli waris AS dan GS mengajukan upaya hukum melalui peninjauan kembali dengan Putusan Nomor 125 PK/PDT.SUS-PAILIT/2015, dalam alasannya pemohon peninjauan kembali justru majelis hakim mempunyai pendapat yang sama, adapun pertimbangan majelis hakim peninjauan kembali yakni sebagai berikut:

"Tidak diperoleh bukti yang cukup bahkan tidak ada bukti sama sekali kalau cessie tersebut telah diberitahukan kepada si berutang sebagaimana diatur di dalam Pasal 613 KUHPerdata, mempedomani Putusan MA RI Nomor $18 \mathrm{~K} / \mathrm{N} / 2000$ antara BPPN melawan PT SA dalam pertimbangan yang menyatakan akta cessie tidak sesuai dengan Pasal 613 KUHPerdata, yang antara lain tidak diberitahukan kepada pihak debitur atau yang berhutang, sehingga demikian keabsahan akta cessie masih harus dipermasalahkan, maka dengan demikian permohonan pailit a quo tidak memenuhi syarat pembuktian yang sederhana."

Amar putusan peninjauan kembali mengabulkan seluruh permohonan pemohon peninjauan kembali, dan membatalkan Putusan Nomor 02/PDT.SUS.PAILIT/2014/PN.Niaga. Mks serta Putusan Nomor 19 K/PDT.SUSPAILIT/2015, dan mengadili sendiri perkara tersebut dengan menolak seluruh permohonan pemohon pailit. Uraian pertimbangan majelis hakim peninjauan kembali, menyatakan pengalihan piutang akta cessie tidak sah dan tidak dapat diberitahukan secara sederhana, karena cessie tidak diberitahukan seharusnya akta tersebut batal demi hukum, ketentuan ini majelis hakim peninjauan kembali hanya mempedomani putusan yurisprudensi sebelumnya yakni di dalam Putusan Nomor 18 K/N/2000.

Mencermati yurisprudensi Putusan Nomor $18 \mathrm{~K} / \mathrm{N} / 2000$ hakim melakukan penafsiran hukum terhadap pembuktian sederhana dalam proses pengalihan piutang dari kreditur lama kepada kreditur baru dengan penggunaan akta otentik atau di bawah tangan harus melalui prosedur bagi kreditur cessionaries mewajibkan untuk melakukan pemberitahuan namun menggunakan prosedur eksplosit juru sita pengadilan negeri. Ketentuan ini jika dilihat di dalam Pasal 613 BW justru tidak adanya kewajiban prosedur pemberitahuan secara resmi, justru dengan diterapkannya kewajiban pemberitahuan melalui juru sita pengadilan akan berdampak efisiensi bagi kreditur untuk menagih utang kepada debitur dengan proses waktu yang lama.

Menurut Setiawan \& Satrio (2010) mengatakan dalam praktik di masa sekarang, dari 
laporan para lawyer yang sampai pada penulis, syarat seperti itu membawa banyak kesulitan dalam praktik, karena sekarang-di samping masalah biaya-para juru sita sudah sangat sibuk dengan tugas-tugasnya sehingga tidak mudah untuk minta agar juru sita menyempatkan waktu untuk memberitahukan telah terjadinya cessie kepada cessus, sehingga tidak perlu pakai eksploit juru sita.

Penggunaan yang secara resmi melalui juru sita pengadilan tidak perlu dilakukan pada saat adanya pengalihan piutang melalui cessionaries. Idealnya pemberitahuan dapat dilakukan melalui juru sita pengadilan pada saat kreditur cessionaries mengajukan upaya hukum baik gugatan wanprestasi maupun permohonan kepailitan terhadap debitur. Bahkan pemberitahuan juga dapat diberitahukan pada saat pengajuan peringatan (somasi) kepada debitur untuk melunasi utang yang diajukan olekh kreditur cessionaries dengan melampirkan buktibukti serta fotocopy adanya pengalihan piutang pada saat mengajukan somasi terhadap debitur.

Pendapat ini diperkuat oleh Volmarr yang mengatakan meskipun cessie telah sah dengan dibuatnya akta cessie yang mengakibatkan beralihnya hak tagih, tetapi untuk mengikat cessus atau debitur, berdasarkan Pasal 613 ayat (2) KUHPerdata pengalihan tersebut harus diberitahukan kepada debitur atau telah diakui atau disetujui oleh debitur (betekening). Kelalaian dalam pemberitahuan kepada cessus berakibat bahwa pembayaran tagihan yang dilakukan oleh cessus kepada cedent atau debitur lama tetap sah, asal cessus dengan jujur beranggapan bahwa cedent masih sebagai krediturnya.

Berdasarkan pendapat tersebut di atas, ketentuan mengenai kewajiban pemberitahuan melalui juru sita pengadilan terhadap peralihan piutang cessie tidak perlu prosedur secara resmi, pemberitahuan yang terlambat tidak menghapus utang debitur, pemberitahuan juga cukup hanya persetujuan dari debitur yang secara jujur mengakui adanya utang, dalam hal ini bisa dilakukan dengan mengirimkan surat peringatan penagihan langsung kepada debitur.

\section{Majelis hakim pada Putusan Nomor} 125 PK/PDT.SUS-PAILIT/2015 yang dalam pertimbangan hukumnya mempedomani Putusan Nomor $18 \mathrm{~K} / \mathrm{N} / 2000$ tidak memberikan kepastian hukum serta perlindungan hukum bagi kreditur dalam ketentuan yang sudah diatur di dalam Pasal 613 BW. Justru penerapan yang dicantumkan di dalam Putusan Nomor 125 PK/ PDT.SUS-PAILIT/2015 akan berpotensi bagi debitur untuk menghindari utang dari kreditur, dengan alasan tidak mengakui utang yang diterimanya pada saat proses pengadilan karena pembuktian mewajibkan adanya eksplosit juru sita pengadilan.

Konsep yang ideal dalam proses pembuktian sederhana yakni adanya kewajiban pemberitahuan pengalihan piutang cessie yang saat ini terjadi inkonsisten putusan pengadilan dalam memutus perkara kepailitan. Penulis sependapat dengan pertimbangan hukum yang diuraikan di dalam Putusan Nomor 02/PDT.SUS. PAILIT/2014/PN.Niaga.Mks dan Putusan Nomor 19 K/PDT.SUS-PAILIT/2015 yang menyatakan tidak diberitahukan adanya pengalihan piutang dari kreditur lama menjadi kreditur baru tidak menjadikan cessie itu batal, debitur tetap tidak terhapus dari segala utang-utangnnya dan pemegang hak cessie tetap mempunyai hak tagih. Pemberitahuan bisa dikategorikan pada saat juru sita pengadilan memanggil para pihak untuk bersidang dalam pengadilan. Dan pemberitahuan 
kepada debitur tidak perlu juga menggunakan juru sita pengadilan bahkan di dalam proses pengajuan somasi yang dibuktikan adanya utang yang telah jatuh waktu dan harus dibayar debitur terhadap kreditur baru merupakan konsep pembuktian sederhana.

Pembuktian sederhana dalam proses kepailitan hanya cukup menyatakan bahwa status kreditur baru yang beralih dari kreditur lama sesuai dengan akta cessie yang dibuktikan di dalam pengadilan sehingga tidak menghapuskan segala utang debitur. Proses mengenai pemberitahuan dapat dilakukan kapan saja dan dapat dilakukan melalui pengajuan somasi kepada debitur serta pengajuan upaya hukum baik itu gugatan wanprestasi maupun kepailitan, sementara itu kreditur juga dalam proses permohonannya mengetahui adanya kreditur lain yang mempunyai utang dengan debitur. Sehingga kreditur pemegang cessie dapat mengajukan proses permohonan kepailitan melalui pengadilan niaga.

Untuk memberikan perlindungan hukum bagi kreditur cessionaries maka perlu dilakukan revisi di dalam Undang-Undang Nomor 37 Tahun 2004 khusus bagi kreditur cessionaries dalam proses kepailitan, sehingga memberikan kepastian hukum majelis hakim pengadilan niaga maupun Mahkamah Agung dalam memutus perkara kepailitan untuk membuktikan secara sederhana adanya pengalihan piutang (cessie).

\section{KESIMPULAN}

Konsep pembuktian sederhana pada Putusan Nomor 02/PDT.SUS.PAILIT/2014/ PN.Niaga.Mks yang dikuatkan oleh Putusan Nomor 19 K/PDT. SUS-PAILIT/2015 serta Putusan Nomor 125 PK/PDT.SUS-PAILIT/2015 dalam pertimbangannya majelis hakim pengadilan niaga dan kasasi berpendapat pemohon pailit selaku kreditur cessionaries telah membuktikan secara sederhana permohonan pailit dengan adanya pemberitahuan pengalihan piutang dibuktikan dengan adanya notice of default dan adanya permohonan kepailitan dari pemohon pailit terhadap termohon pailit. Namun pertimbangan majelis hakim peninjauan kembali justru berpendapat lain.

Adapun pertimbangannya majelis hakim peninjauan kembali mempedomani Putusan Nomor 18 K/N/2000 yang menyatakan pemohon pailit tidak dapat membuktikan secara sederhana permohonannya dikarenakan tidak diberitahukannya pengalihan piutang cessie terhadap cessus secara resmi melalui juru sita pengadilan.

Jika ditinjau dalam ketentuan Pasal 613 BW tidak ada pengaturan mengenai harus diberitahukannya debitur melalui eksploit juru sita pengadilan sehingga konsep pembuktian sederhana dalam proses kepailitan hanya cukup menyatakan bahwa status kreditur baru (cessionaries) yang beralih dari kreditur lama (cedent) sesuai dengan akta cessie yang dibuktikan di dalam pengadilan dengan memenuhi kewajiban adanya pemberitahuan kepada debitur baik pada saat mengajukan somasi maupun pada saat mengajukan permohonan kepailitan. Dengan adanya inkonsistensi putusan pengadilan niaga dalam memutus perkara kepailitan terhadap pemohon pailit cessie maka perlu sebaiknya dilakukan revisi Undang-Undang Nomor 37 Tahun 2004 mengenai pembuktian sederhana terhadap ketentuan mengenai cessie dalam proses kepailitan, sehingga menciptakan suatu perlindungan hukum yakni kepastian hukum, keadilan hukum, dan kemanfaatan hukum. 


\section{DAFTAR ACUAN}

Amiruddin \& Asikin, Z. (2010). Pengantar metode penelitian hukum. Jakarta: PT Raja Grafindo.

Asser, C. (1991). Pengajian hukum perdata Belanda (Hendleiding tot de beofening van het Nederlands bergerlijk recht). Jakarta: Dian Rakyat.

Badrulzaman, M.D. (1984). Bab-bab tentang credietverband, gadai \& fidusia. Bandung: IKAPI.

Baskara, A. (2014, Maret). Alternatif penyelesaian hak tanggungan dengan cara lelang. Journal Rechstaat, 8 (1), 1-6.

Budiono, H. (2010). Ajaran hukum perjanjian \& penerapannya di bidang kenotariatan. Bandung: Citra Aditya Bakti.

Butarbutar, E.N. (2010). Arti pentingnya pembuktian dalam proses penemuan hukum di peradilan perdata. Mimbar Hukum, 22 (2), 347-359.

Cahyono, A.B. (2004, Desember). Cessie sebagai bentuk pengalihan piutang atas nama. Lex Jurnalica, 2 (1), 13-20.

Harahap, M.Y. (2012). Hukum acara perdata. Jakarta: Sinar Grafika.

Juanda, H.E. (2016). Kekuatan alat bukti dalam perkara perdata menurut hukum positif Indonesia. Jurnal Ilmiah Galuh Justisi, 4 (1), 27-46.

Pratama, B. (2014, Agustus). Kepailitan dalam putusan hakim ditinjau dari perspektif hukum formil \& materil. Jurnal Yudisial, 7 (2), 157-172.

Purwadi, A. (2011, Mei). Penerapan ketentuan kepailitan pada bank yang bermasalah. Perspektif, XVI(3), 128-139.

Putriyanti \& Wijayanta, T. (2010, Oktober). Kajian hukum tentang penerapan pembuktian sederhana dalam perkara kepailitan asuransi. Mimbar Hukum, 22 (3), 482-497.

Puang, R.V. (2011). Penerapan asas pembuktian sederhana dalam penjatuhan putusan pailit. Bandung: PT Sarana Tutorial Nurani Sejahtera.

Rochmawanto, M. (2015, Februari). Upaya hukum dalam perkara kepailitan. Jurnal Independent, $3(2), 25-35$.

Saifullah. (2015). Tipilogi penelitian hukum kajian sejarah, paradigma \& pemikiran tokoh. Malang: CV Cita Intrans Selaras.

Setiawan, R., \& Satrio, J. (2010). Penjelasan hukum tentang cessie. Jakarta: PT Gramedia.

Shubhan, M.H. (2014). Hukum kepailitan, prinsip, norma, \& praktik di peradilan. Jakarta: Kencana Media Group.

Suci, I.D.A., \& Poesoko, H. (2016). Hukum kepailitan kedudukan \& hak kreditur separatis atas benda jaminan debitur pailit. Yogyakarta: Laksbang Pressindo.

Suharnoko \& Hartati, E. (2012). Doktrin subrogasi, novasi, dan cessie, dalam Kitab UndangUndang Hukum Perdata Nieuw Nederlands Burgerlijk Wetboek, Code Civil Perancis, \& Common Law. Depok: Fakultas Hukum Universitas Indonesia.

Sunarmi. (2016). Konseputang dalam hukum kepailitan dikaitkan dengan pembuktian sederhana (Studi Putusan No: 04/Pdt.Sus.Pailit/2015/Pn.Niaga. Jkt.Pst). USU Law Journal, 4(4), 30-39.

Usman, R. (2016. April). Kepailitan terhadap bank berdasarkan asas keseimbangan sebagai perwujudan perlindungan kepentingan nasabah penyimpan. Badamai Law Journal, 1(1), 141158.

Wahyudi, J. (2012, Mei). Dokumen elektronik sebagai 
alat bukti pada pembuktian di pengadilan. Perspektif, XVII(2), 118-126.

Zulaeha, M. (2015, Juli-Desember). Mengevaluasi pembuktian sederhana dalam kepailitan sebagai perlindungan terhadap dunia usaha di Indonesia. JHAPER, 1(1), 171-187. 